\title{
Transformatie van kennisinfrastructuur
}

\section{De juiste kennis op de juiste plek}

\author{
Paul Poortvliet
}

Published online: 31 October 2018

(C) Bohn Stafleu van Loghum is een imprint van Springer Media B.V., onderdeel van Springer Nature 2018

\begin{abstract}
De transformatie in het sociale domein is een grote opgave en nog volop gaande. Doel van de decentralisaties is om zorg en ondersteuning effectiever en dichter bij inwoners te organiseren, om zo meer maatwerk te leveren en kosten te besparen. De domeinen van zorg, welzijn, participatie, jeugd, wonen en ruimtelijke ordening raken daarbij steeds meer met elkaar verbonden. Vraagstukken worden complexer en vragen om een integrale oplossing. Dit is een proces van proberen, onderzoeken, reflecteren, leren en doorontwikkelen. Een effectieve kennisinfrastructuur is nodig om dit proces te ondersteunen.
\end{abstract}

\section{Visie op kennisinfrastructuur}

Het beeld van kennisontwikkelaars en verspreiders aan de ene kant (wetenschap, onderwijs en kennisinstituten) en de kennisgebruikers (zoals professionals, inwoners, bestuurders) aan de andere kant past niet goed bij actuele inzichten over een effectieve kennisinfrastructuur. Het is al langer duidelijk dat het bij de ontwikkeling en toepassing van kennis om een interactief proces gaat, waarbij wetenschap, beleid, praktijk en onderwijs nauw met elkaar verbonden zijn, elk met een eigen rol, maar elkaar voedend in het proces. Hierbij gaat het om het uitwisselen van ervaringen, het overbrengen van innovaties en het organiseren van een groter adaptief en lerend vermogen van professionals op alle niveaus (politiek, bestuurlijk, management, uitvoering) $[1,2]$.

Kim Putters stelt dat nu gemeenten de stap maken van 'transitie naar transformatie' het extra van belang is te weten wat goed rendeert in het sociale domein. 'Om samen uit te zoeken wat wel en niet werkt, en

\section{P. Poortvliet $(\bowtie)$}

Bosman \& Vos, Rijswijk, Nederland

ppoortvliet@bosmanvos.nl op een gedegen manier te gaan experimenteren met aanpakken die burgers effectief en op een passende manier kunnen activeren. Daarvoor is landelijk een sterke opleidings- en kennisinfrastructuur nodig, en lokaal de ruimte voor actieve reflectie en kennisdeling' [3].

De Raad voor Volksgezondheid en Samenleving stelt: 'Voor goede, patiëntgerichte zorg zijn naast externe kennis ook andere kennisbronnen nodig: klinische expertise, lokale kennis, kennis afkomstig van patiënten, kennis van de context, de leefomstandigheden en voorkeuren van patiënten, de setting waarin zorg plaatsvindt en van de waarden die in het geding zijn. Het gaat verder dan het lokaal implementeren van externe kennis. Het betekent een continu proces van samen leren en verbeteren. En het betekent een andere benadering van onderwijs en onderzoek' [4].

\section{Te veel nadruk op ontsluiten en verspreiden van} kennis

Toch zie je nog geregeld klassieke opvattingen over de kennisinfrastructuur. Daarbij start het bij onderzoek en eindigt het bij het implementeren, uitrollen of landen van onderzoeksresultaten in de praktijk.

Het kennisaanbod van de publieke kennisorganisaties en de kennisvraag van gemeenten sluiten vaak niet goed op elkaar aan. De gegevens die de publieke kennisorganisaties verzamelen zijn bijvoorbeeld niet altijd direct bruikbaar voor de beantwoording van gemeentelijke kennisvragen [5].

De vertaalslag van het kennisaanbod naar de eigen lokale situatie is groot [6]. In de ontsluiting ligt nu nog te veel nadruk op het schriftelijk overbrengen van kennis. Stappenplannen, handleidingen, goede voorbeelden en onderzoeksrapporten hebben voor de uitvoeringspraktijk vaak een beperkte waarde en worden lang niet altijd gebruikt. Dit komt doordat ze te ab- 
stract of te uitgebreid zijn, waardoor een praktische vertaling naar het eigen primaire proces lastig is en te veel moeite kost.

Kennisinstituten doen al meer om kennis toegankelijker te maken in de vorm van compacte informatie, visualisaties (infographics) en filmpjes. Ook zijn er initiatieven om kennis centraal en integraal (over meerdere thema's) te ordenen op digitale kennispleinen. Toch is ontsluiting van kennis slechts een deel van wat nodig is om tot een effectieve kennisinfrastructuur te komen.

\section{Behoefte aan kennisdeling vanuit verbinding}

In het veld bestaat er een behoefte aan meer interactieve vormen van kennisdeling [6, 7]. De Vereniging van Nederlandse Gemeenten geeft in een visiestuk aan dat gemeenten vooral behoefte hebben aan meedenkers en medeontwikkelaars [8]. 'Ontwikkelaars die ontwikkelprocessen faciliteren en effectief/productief kunnen maken. Adviseurs die vraaggericht en onafhankelijk kunnen werken. Onderzoekers die helder antwoord geven op vragen over effectiviteit (wat werkt?) en daarbij onderzoeksmethodieken inzetten die behulpzaam zijn bij transformerend beleid en professionele praktijken.'

\section{Verbindende rol van de kennisprofessional}

De 'kennisprofessional' heeft een belangrijke verbindende en intermediaire rol in de kennisnetwerkstructuur. Dit kan iemand zijn die werkt in een landelijk of regionaal kennisinstituut, staf/adviseur is binnen een organisatie of verbonden is aan een academische werkplaats. $\mathrm{Zij}$ is een van de deelnemers in landelijke en regionale netwerken (onderzoek, beleid, wetenschap en onderwijs). Meerwaarde van deze professional zit in het vermogen om te verbinden, systematisch kennis te zoeken en te ontsluiten. Ze doet dit in interactie (cocreatie) met degenen die de uitvoeringspraktijk vormgeven (bestuur, management, professional en inwoner), bijvoorbeeld als lid van een projectof stuurgroep. In de interactie met de uitvoeringspraktijk ontstaat meer toegevoegde waarde.

Waardevolle vormen zijn bijvoorbeeld een dialoog met een kennisprofessional/expert die vanuit haar kennis en ervaring goed luistert, meedenkt, spiegelt en confronteert, en kennis in de lokale situatie inbrengt en daarbij zelf ook weer nieuwe inzichten krijgt. Of iemand die meekijkt en meehelpt bij het maken van een wijkanalyse, en die bredere kennis heeft en voorbeelden kent uit andere gemeenten, die een gesprek voert dat leidt tot eyeopeners en concrete ideeën voor een lokale aanpak.

De rol van de kennisprofessional is ook het met elkaar verbinden van mensen en het faciliteren van een onderlinge uitwisseling van kennis. Dit betekent dat zij ook gevoel heeft voor processen, belangen en ambities van betrokken partijen, en beschikt over ver- anderkundige en adviesvaardigheden. Zij brengt zelf ideeën en kennis in vanuit ervaring en onderzoek in andere regionale, landelijk en internationale netwerken. Bijvoorbeeld doordat zij deelneemt aan verschillende netwerkactiviteiten of door digitale ontsluiting en uitwisseling van kennis.

\section{Verbinding tussen lokaal, regionaal en landelijk}

Met de decentralisatie in het sociale domein doemt nog een ander vraagstuk op. De transformatie vindt primair plaats in een lokale en regionale context: hoe zorg je ervoor dat een kennisinfrastructuur niet versnipperd raakt en iedereen opnieuw het wiel gaat uitvinden? Hoe zorg je voor een goede verbinding waarin je leert van elkaar [5]? Het Rathenau Instituut waarschuwt als volgt: 'De wetenschappelijke onderbouwing van hoe gemeenten zorg en hulp bieden aan hun inwoners staat onder druk. De kennis over gezondheidszorgvraagstukken dreigt versnipperd te raken, nu de gemeenten sinds 2015 verantwoordelijk zijn ...' Het Rathenau Instituut adviseert centrale regie van het ministerie van VWS bij de basale kennisopbouw.

Deze centralistische benadering past echter niet goed bij een nieuwe visie op de kennisinfrastructuur. Ook op systeemniveau moeten we kijken naar nieuwe modellen, veel meer vanuit een netwerkgedachte, met verbindingspunten en gedeelde kennisbases.

\section{Transformatie van de kennisinfrastructuur}

Voor de transformatie in het sociale domein is een effectieve kennisinfrastructuur onontbeerlijk. Allereerst is het van belang om in het sociale domein een heldere en gedeelde visie op kennisinfrastructuur te vormen. Het komt nog te veel voor dat betrokkenen (financiers, beleidsmakers, bestuurders) hier met een klassieke bril naar kijken en zo beslissingen nemen. Dit leidt tot investeringen met publiek geld die weinig zoden aan de dijk zetten en die niet bijdragen aan vernieuwing en een betere en betaalbare zorg en ondersteuning.

Vervolgens is het zaak te experimenteren met nieuwe vormen en rollen. Deels gebeurt dit al, denk aan regionale (academische) werkplaatsen en het programma integraal werken in de wijk (IWW). Bij IWW werken landelijke kennisinstituten samen met regionale Werkplaatsen Sociaal Domein.

Toch moet het allemaal nog wat fundamenteler en radicaler. De stapjes naar een nieuwe kennisinfrastructuur zijn klein en verlopen traag, en worden veelal gezet vanuit bestaande structuren. Het vraagt om een andere benadering.

Hoe dit er concreet moet uitzien is op voorhand niet duidelijk. Hiervoor kan je inspiratie op doen bij kennisinfrastructuren in andere sectoren en andere disciplines. Denk daarbij aan land- en tuinbouw, of aan kunstmatige intelligentie. Denk op een crea- 
tieve manier na over nieuwe vormen en experimenteer hiermee. Als je de kennisinfrastructuur ziet als netwerken met een veelheid aan verschillende kernen, bekijk dan wat dit fundamenteel voor de inrichting betekent (het systeem). Je kan hierbij de volgende vragen stellen: hoe faciliteer je deze netwerken zo goed mogelijk? Welke organisatievormen horen daar bij? Hoe financier je deze? Welke vormen zijn effectief en doelmatig? Welke technologische mogelijkheden zijn er? Kun je kennis met slimme interactieve ICT-toepassingen en kunstmatige intelligentie meer laten aansluiten bij de lokale dagelijkse uitvoeringspraktijk? Is een personalisering van de kennisinfrastructuur mogelijk? Concreet betekent dit dat je bijvoorbeeld als professional (of als inwoner/cliënt/patiënt) die kennis aangereikt krijgt en deelt die qua vorm en inhoud precies past bij jouw situatie en jouw behoefte - de juiste kennis op de juiste plek.

\section{Literatuur}

1. Gezondheidsraad. Sociaal werk op solide basis. Den Haag: Gezondheidsraad; 2014.
2. Wetenschappelijke Raad voor het Regeringsbeleid. Naar een lerende economie. Investeren in het verdienvermogen van Nederland. Amsterdam: Amsterdam University Press; 2013.

3. Putters K. Een lokaal sociaal contract. Voorwaarden voor eeninclusieve samenleving. Den Haag: Sociaalen Cultureel Planbureau; 2018.

4. Raad voor Volksgezondheid en Samenleving. Zonder context geen bewijs. Over de illusie van evidence-based practice in de zorg. Den Haag: RVS; 2017.

5. Faasse P, Koens L. Gezond verstand. Publieke kennisorganisaties in de gezondheidszorg. Den Haag: Rathenau Instituut; 2017.

6 . Veer K van der. Hoe zoeken en delen beleidsadviseurs van de gemeente kennis? Utrecht: Integraal werken in de Wijk; 2017.

7. Vereniging van Nederlandse Gemeenten. Visiedocument Kennisinfrastructuur sociaal domein. Den Haag: VNG; 2016.

8. PoortvlietEP, Lameris P, Pasman H.Evaluatie en impactanalyse academische werkplaatsen publieke gezondheid. Den Haag: Bosman \& Vos; 2015. 